\title{
Diversity of Rhizobacteria Associated with Sorghum Wild Relatives in Assosa Zone of Ethiopia and Their Ability to Solubilize Phosphate
}

\author{
Eleni Belay, Befekadu Teshome* \\ Ethiopian Biodiversity Institute, Microbial Biodiversity Institute, Bacteria and Fungus Biodiversity Case-team, Addis Ababa, Ethiopia
}

Email address:

Beftesh@gmail.com (B. Teshome)

${ }^{*}$ Corresponding author

To cite this article:

Eleni Belay, Befekadu Teshome. Diversity of Rhizobacteria Associated with Sorghum Wild Relatives in Assosa Zone of Ethiopia and Their Ability to Solubilize Phosphate. Frontiers in Environmental Microbiology. Vol. 7, No. 2, 2021, pp. 63-68. doi: 10.11648/j.fem.20210702.13

Received: February 11, 2021; Accepted: April 16, 2021; Published: May 21, 2021

\begin{abstract}
Culture based diversity of Rhizobacteria associated with Sorghum wild relatives were identified by this study. Rhizobacteria, which include rhizosphere bacteria, rhizoplane bacteria and endophytic bacteria were isolated and identified. The isolates were also evaluated and screened for their ability to solubilize phosphates on Pikovskaya's agar plates. One hundred twenty-six rhizobacteria were isolated on nutrient agar from the samples. Out of these Rhizobacterial isolates, 21 of them were endophyte bacteria, 40 of them were rhizosphere bacteria and 65 of them were rhizoplane bacteria. The 126 isolated rhizobacteria were clustered into 36 similar representative Morphotype groups. And, they were identified using GEN III Biolog microbial identification system. Gram negative rhizobacteria were more predominant than Gram positive rhizobacteria. Genus Pseudomonas was found as the most dominant Rhizobacterial taxa among the identified P-solubilizing Rhizobacteria and NonP-solubilizing Rhizobacteria isolates. Forty seven percent (47.2\%) of the clustered rhizobacterial isolates showed clearly visible haloes $(\geq 0.50 \mathrm{~cm})$ around their colonies on Pikovskaya's agar after seven days of incubation at $30 \pm 2^{\circ} \mathrm{C}$. They showed a significant difference of solubilization index (SI) $[\mathrm{p}<0.05]$ and ranged from 1.3 to 5.3 with a mean value of 2.4. Gram positive bacteria (Bacillus cibi) produced the largest solubilisation index when compared with the Gram-negative isolates. This study indicated that P-solubilizing rhizobacteria associated with Sorghum Wild Relative have very large phosphate solubilization index. Thus, it is recommended to include them in research programs that intend to screen P-solubilizing bacteria for microbial inoculant development.
\end{abstract}

Keywords: Rhizobacterial Diversity, Sorghum Wild Relatives, P-solubilizing Rhizobacteria, Biolog

\section{Introduction}

Diverse microorganisms which exist around the plant rhizosphere modulate the physiology and morphology of plants and by that they improve plant growth through hormone production, nutrient uptake and protecting plants from pathogens $[3,19]$. The plant rhizosphere is a small tiny zone of soil which encompasses the plant root, where high abundance and diversity of micro-organisms flourish [29]. The dominant bacteria which colonize this zone are known as rhizobacteria [8]. They are characterized by aggressive colonization and subsequent establishment on plant roots. Some of this diverse bacterial species are culturable and others are yet unculturable. Gram negative rhizobacteria predominate the rhizosphere $[8,24,25]$.

Multiple interactions occur among the plant root, soil and bacteria in the dynamic environment of the rhizosphere. The soil is under the influence of plants through root exudates or rhizodeposits, plant litter, and nutrient exchanges [7]. Rhizodeposits are suitable for binding bacteria and such environments are richer in microflora and available nutrients than the bulk soil [3]. Plants absorb water and mineral nutrients from the soil and release rhizodeposits into the soil through the interface between root and soil. The different forms of the rhizodeposits facilitate below-ground interactions between plants and microorganisms and consequently affect the biodiversity of the rhizosphere. Root-microbial interactions involve myriads of microorganisms and are very 
complex [21]. Most studies characterized rhizobacteria by isolating bacteria from the rhizosphere soil of cultivated plants. The most commonly characterized and identified Rhizobacterial genera are: Acetobacter, Acinetobacter, Alcaligenes, Arthrobacter, Azoarcus, Azospirillum, Azotobacter, Bacillus, Beijerinckia, Burkholderia, Derxia, Enterobacter, Gluconacetobacter, Herbaspirillum, Klebsiella, Ochrobactrum, Pantoae, Pseudomonas, Rhodococcus, Serratia, Stenotrophomonas, and Zoogloea [1].

Different factors determine the microbial diversity in the agricultural fields. Some of the important factors that directly affect the diversity of rhizobacteria are spatial and temporal variability, plant species, plant age, genotypes of plants, and root exudates. In addition, agricultural practices and ecological disturbances may affect the structure and diversity of soil microbial community [1]. For example, intensive land-use reduces metabolic diversity of rhizobacteria which by its turn may reduce the soils' resistance to stress or disturbance [8].

Plant beneficial microbial bio-resources as an alternative solution for the many destructive and high intensity agricultural practices are being promised and considered to support ecofriendly crop production [23, 10]. Particularly, plant growth promoting rhizobacteria has gained worldwide importance and acceptance for benefiting agriculture and functioning ecosystem [10, 14, 23, 27]. To this end, a diverse array of rhizobacteria had been isolated from cultivated plants rhizosphere and has been used for maintaining soil fertility [8] but selecting and characterizing rhizobacteria isolated from wild relatives of crops which are grown naturally in relatively undisturbed environment has not that much been done before. But it is important to search and find novel microbial strains from such undisturbed natural environments that can be used for microbial inoculant development. In light of this assumption, this study had attempted to decipher the rhizobacterial diversity associated with sorghum wild relatives and evaluated phosphate solubilization ability of the isolated bacterial species.

\section{Materials and Methods}

\subsection{Description of Study Area}

Sorghum wild relative samples were collected from Assosa zone of Benishangul-Gumuz region of Ethiopia. The sample collection site is shown in Figure 1. It comprises three woredas (Administration units in a zone) which are found in Assosa zone. The names of the three woredas are Assosa zuria, Bambasi and Oda. The GPS data of sample collection sites are located between the latitudinal range: $009^{\circ} 44.344^{\prime} \mathrm{N}$ $10^{\circ} 05.4913 \mathrm{~N}$ and longitudinal range: $32^{\circ} 16.1941^{\prime} \mathrm{E}-$ $35^{\circ} 11.9250^{\prime} \mathrm{E}$ with an altitude range: $1005-1508 \mathrm{~m}$ a.s.l.
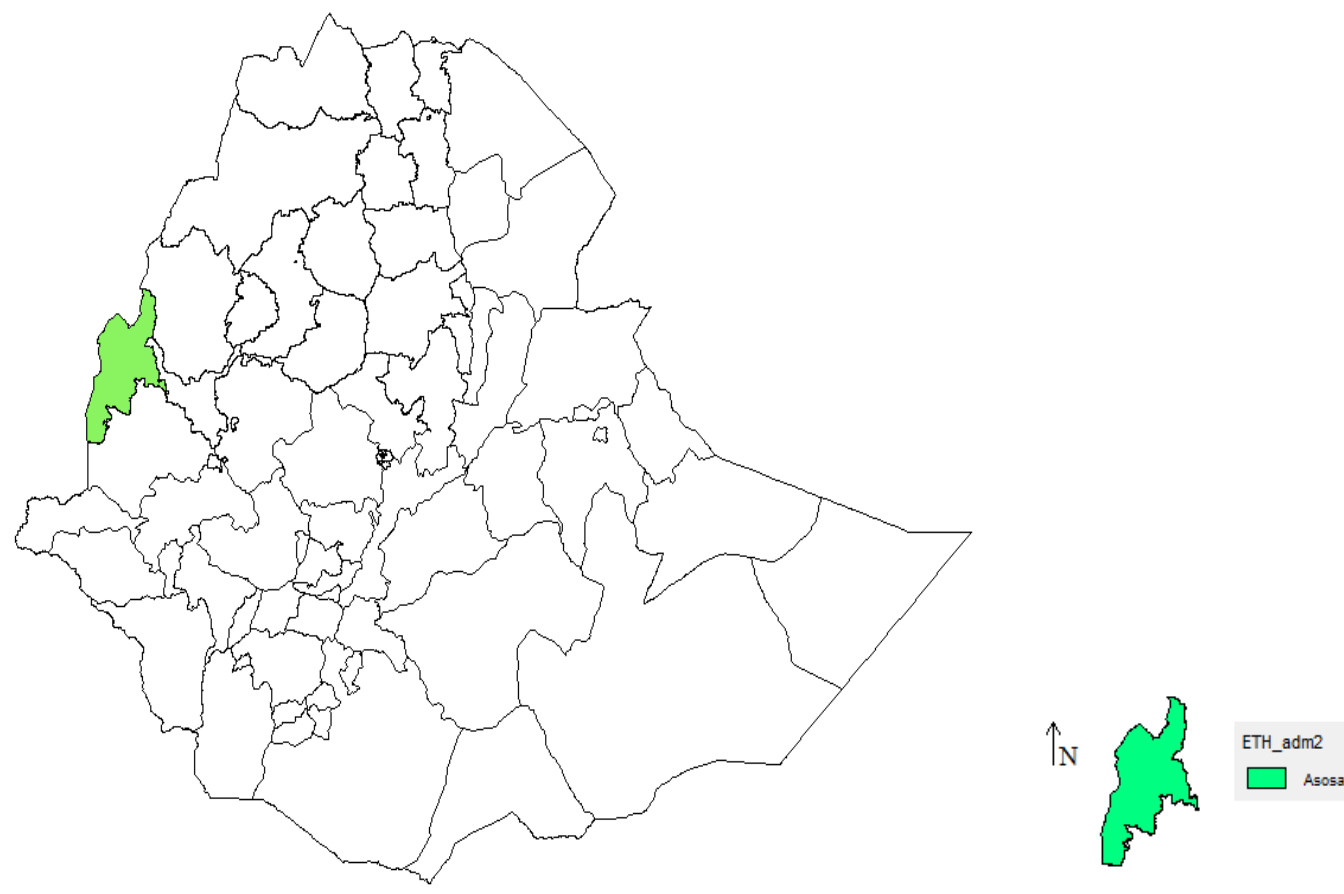

Figure 1. Map of study area:-Assosa zone.

\subsection{Sample Collection}

Eight sorghum wild relative (SWR) varieties found in the study area were included during sample collection. These varieties are known by their local names: Bundule, Abendu, Ereregn, Abirbid, Aduhen, Gelabro, Agamo, and Bokona. Plant roots with approximately $50 \mathrm{~g}$ of adhering soil were uprooted and collected in a sterile plastic bag. Root adhering soil samples were collected carefully to keep the soil intact around the root. On top of it, rhizosphere soil was also collected from each SWR plants. The samples were transported to Ethiopian Biodiversity Institute, Microbiology Laboratory under ice-box and were kept at $4^{\circ} \mathrm{C}$ until use [9, $16,26]$

\subsection{Isolation of Rhizobacteria}

Three different sample types: root, root washing solution 
and rhizosphere soil were employed to isolate rhizobacteria. In order to homogenize and remove bacterial cells from the rhizosphere soil, 1.0 gram of soil were mixed in $9.0 \mathrm{ml}$ of saline solution $(0.85 \% \mathrm{NaCl})$ [1/10 (wt./vol)] and vortexed for $5 \mathrm{~min}$. $[9,28]$. The root adhering soil were washed and dislodged from the roots using sterile distilled water by shaking at $250 \mathrm{rpm}$ for 20 minutes. The rhizoplane bacteria were isolated from the root washing solutions [5]. Washed roots were surface sterilized using three steps surface sterilization technique in $99 \%$ ethanol for $1 \mathrm{~min}, 3 \% \mathrm{NaOCl}$ for 6 minutes, and 99\% ethanol for 30 seconds and followed by rinsing with sterile distilled water for 6 times [16]. These washed and sterilized roots were used to isolate bacterial endophytes. Roots were homogenised and macerated with a sterile mortar and pestle after checking the sterility of the roots [13].

Serial dilutions $\left(10^{-2}\right.$ to $\left.10^{-4}\right)$ were prepared for the homogenized rhizosphere soil, root washing solutions and homogenised roots for aseptic inoculation. Inoculums $(0.1 \mathrm{ml}$ each) of the diluted samples were spread onto Nutrient agar plates and incubated at $30 \pm 2{ }^{\circ} \mathrm{C}$ for $48 \mathrm{~h}[22,28]$. Purification of bacteria was done by selecting and re-streaking bacterial colonies with distinct and peculiar morphologies [9].

\subsection{Screening of P-solubilizing Rhizobacteria}

Phosphate solubilization ability of the isolated bacteria was determined on Pikovskaya's agar. Bacterial isolates were spotted onto Pikovskaya's agar and incubated for 7 days at 30 $\pm 2^{\circ} \mathrm{C}$. Positive phosphate solubilization was detected by the presence of halo zone around the bacterial colony. The halo zone of clearance (HD) and the colony diameter (CD) of bacteria in the Pikovskaya's agar plate were measured using caliper [20]. The solubilization index (SI) of the isolates were calculated using the formula: $\mathrm{SI}=(\mathrm{CD}+\mathrm{HD}) / \mathrm{CD}$ [6]. Triplicate plates were used for each isolate.

\subsection{Identification of Rhizobacteria}

Biochemical identification including the carbohydrate fermentation patterns and chemical sensitivity tests were determined using GEN III Biolog bacterial identification system kit. Pure culture of bacterial isolates was grown on Biolog BUG agar plates at $30 \pm 2{ }^{\circ} \mathrm{C}$ for $20-24$ hours. Single colonies were swabbed and suspended in inoculating fluid $\mathrm{A}$. Cell suspensions $(100 \mu \mathrm{l})$ adjusted at $90-98 \%$ transmittance was pipetted into 96 well Biolog Micro-plates for 71 carbon source utilization assays and 23 chemical sensitivity assays.
Panels were incubated at $30 \pm 2^{\circ} \mathrm{C}$ for $20-24$ hours. The micro-plates were inserted into the Omnilog automatic system and the identification process was carried out using GEN III Biolog-Omnilog identification system software [4].

\subsection{Data Analysis}

SPSS software version 25 was used for data analysis [12]. Descriptive statistics was performed to organize and describe data. Analysis of Variance (ANOVA) was employed as a statistical test for measuring significances of differences between mean counts of microbial groups. P-value less than $0.05(\mathrm{p}<0.05)$ was taken as significant. For mapping study area, DIVA_GIS 7.5.0 [11] was used.

\section{Results and Discussions}

\subsection{Rhizobacterial Isolation}

One hundred twenty-six rhizobacteria were isolated on nutrient agar from the composite samples. Out of these Rhizobacterial isolates, 21 of them were endophyte bacteria which were isolated from root, 40 of them were rhizosphere bacteria which were isolated from rhizosphere soil and 65 of them were rhizoplane bacteria which were isolated from the root washing solutions. Due to lack of sufficient GEN III microplate necessary for identification of the 126 isolated rhizobacteria, they were clustered into 36 similar representative Morphotype groups. Similarity of colony morphology and Gram staining result were the basis for clustering the bacterial isolates. Eight of the clustered Rhizobacterial isolates were endophyte bacteria, 14 of them were rhizosphere bacteria and the rest 14 bacterial isolates were rhizoplane bacteria (Table 1). The result indicated that a greater number of rhizobacteria is isolated from the soil and root washing solutions than the rhizobacteria isolated from the root.

\subsection{Screening of P-solubilizing Rhizobacteria}

Evaluation of phosphate solubilization ability for the 36 bacterial isolates were done on Pikovskaya's agar plates. Forty seven percent of them showed clearly visible haloes $(\geq 0.50 \mathrm{~cm})$ around their colonies after seven days of incubation (Table 1). They showed a significant difference of solubilization index $(\mathrm{SI})[(\mathrm{p}<0.05]$ and ranged from 1.3 to 5.3 with a mean value of 2.4 .

Table 1. Frequency distribution of clustered rhizobacteria with p-solubilization ability.

\begin{tabular}{llll}
\hline Sample type & No of Rhizobacterial isolates & No of P-solubilizers & No of Non P-solubilizers \\
\hline Root & 8 & 5 & 3 \\
Soil & 14 & 9 & 5 \\
RWS & 14 & 3 & 11 \\
Total & 36 & $17(47.2 \%)$ & $19(52.8 \%)$ \\
\hline
\end{tabular}

Key: RWS: Root Washing Solution.

\subsection{Identification of Rhizobacteria}

Twenty three of the 36 Rhizobacterial isolates were identified using Biolog-Omnilog bacterial identification system (Table 2). 
Table 2. Biolog identification result of rhizobacteria isolated from sorghum wild relatives' root, soil and root washing solution.

\begin{tabular}{|c|c|c|c|c|}
\hline No. & Isolate ID & PSI & Identified bacteria species & Gram staining \\
\hline 1 & AWSR RWS1A & 2.1 & Bacillus cibi & $\mathrm{GM}^{+}$Rods \\
\hline 2 & AWSR RWS2A & Non & Pseudomonas viridilivida & GM$^{-}$Rods \\
\hline 3 & AWSR RWS2B & Non & Bacillus amyloliquefaciens & $\mathrm{GM}^{+}$Rods \\
\hline 4 & AWSR RWS3B & Non & Pseudomonas viridilivida & GM $^{-}$Rods \\
\hline 5 & AWSR RWS4A & 1.6 & Pseudomonas putida biotype $B$ & GM$^{-}$Rods \\
\hline 6 & AWSR RWS4C & Non & Stenotrophomonas rhizophila & GM $^{-}$Rods \\
\hline 7 & AWSR RWS6A & 1.5 & Serratia marcescens ss marcescens & GM Rods \\
\hline 9 & AWSR R1A & 3.4 & Pseudomonas viridilivida & GM$^{-}$Rods \\
\hline 10 & AWSR R2A & 5.3 & Bacillus cibi & $\mathrm{GM}^{+}$Rods \\
\hline 11 & AWSR R4A & 1.7 & Pseudomonas putida biotype $B$ & GM$^{-}$Rods \\
\hline 12 & AWSR R4B & Non & Pseudomonas tolaasii & GM- Rods \\
\hline 13 & AWSR R11A & 2.6 & Pseudomonas putida biotype $B$ & GM $^{-}$Rods \\
\hline 14 & AWSR R12A & Non & Pseudomonas tolaasii & GM- Rods \\
\hline 15 & AWSR R13A & 2 & Pseudomonas viridilivida & GM $^{-}$Rods \\
\hline 16 & AWSR R13B & Non & Pseudomonas synxantha & GM$^{-}$Rods \\
\hline 18 & AWSR S7A & Non & Lactobacillus mali & GM$^{-}$Rods \\
\hline 19 & AWSR S10 C2 & 2.9 & Pseudomonas tolaasii & GM $^{-}$Rods \\
\hline 20 & AWSR S14A & 1.6 & Pseudomonas putida biotype $B$ & GM $^{-}$Rods \\
\hline 21 & AWSR S15B & 1.8 & Chryseobacrerium gleum/indologenes & $\mathrm{GM}^{-}$Rods \\
\hline 22 & AWSR S15C & Non & Pseudomonas viridilivida & GM $^{-}$Rods \\
\hline 23 & AWSR S17A & 3.2 & Pseudomonas synxantha & $\mathrm{GM}^{-}$Rods \\
\hline
\end{tabular}

Key: ASWR: Assosa Sorghum Wild Relative, RWS: Root Washing Solution, S: Soil, R: root, PSI: Phosphate solubilization index and GM: Gram's staining.

The twenty three identified Rhizobacterial isolates belong to 8 bacterial genera. These are Pseudomonas (60.9\%), Bacillus (13.3\%), Stenotrophomonas (4.3\%), Serratia (4.3\%), Enterobacter (4.3\%), Ochrobactrum (4.3\%), Lactobacillus (4.3\%), and Chryseobacrerium (4.3\%).

\subsubsection{Diversity of P-solubilizing Rhizobacteria}

Thirteen of the twenty-three identified bacteria were Psolubilizing rhizobacteria and belong to 5 bacterial genera. These are Pseudomonas (61.5\%), Bacillus (15.4\%), Serratia (7.7\%), Ochrobactrum (7.7\%) and Chryseobacrerium (7.7\%). The most predominant bacterial species are Pseudomonas putida biotype $B$ (30.8\%), followed by Pseudomonas viridilivida (15.4\%) and Bacillus cibi (15.4\%)
[Figure 2]. The identified P-solubilizing Rhizobacteria isolates were dominated by Gram negative rhizobacteria accounting for $80.4 \%(11 / 13)$ [Figure 2, Table 2]). But Grampositive isolate showed the largest solubilisation index (Bacillus cibi) when compared with Gram negative isolate. Previous studies by other researchers showed that Gram negative rhizobacteria are favored more by the rhizosphere of many agriculturally important cultivated plants than the Gram positives $[15,17,18]$. The largest solubilisation index was also produced by Gram negative isolate than the Grampositive isolates. Repeated sub-culturing caused some of the isolates to lose their capacity for phosphate solubilisation as previously reported in many other studies [17].

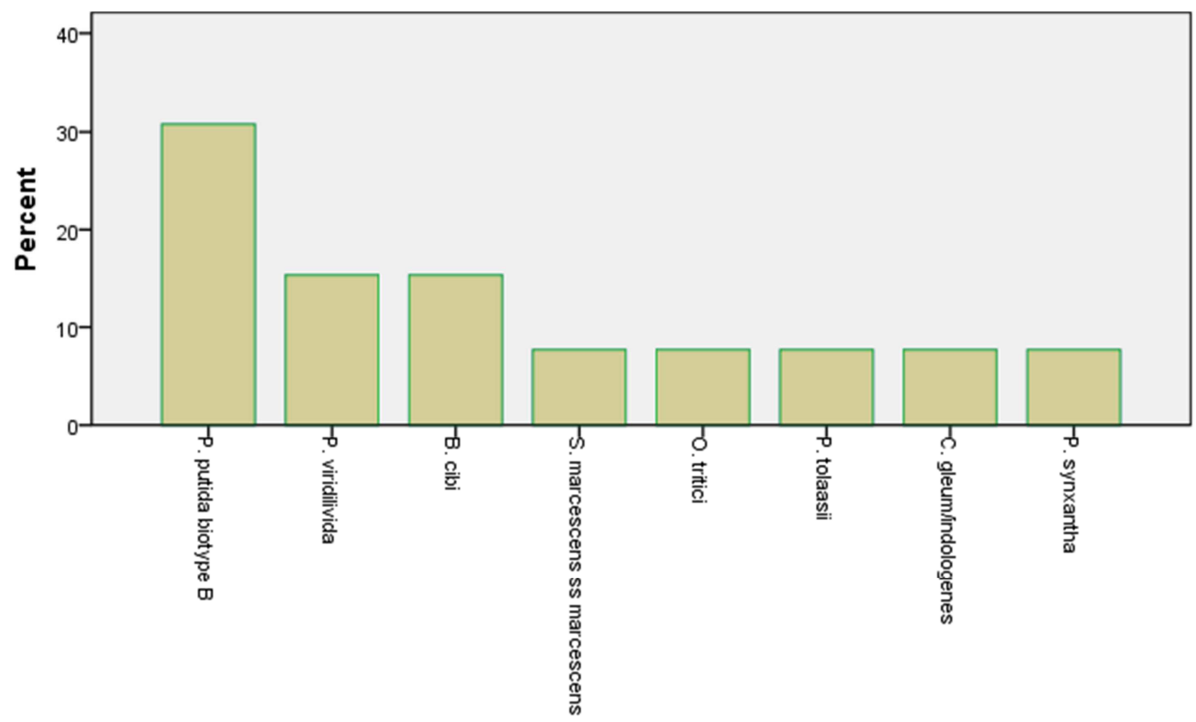

Figure 2. Percent distribution of identified phosphate solubilizing rhizobacteria. 
The highest number of p-solubilizing rhizobacteria was obtained from the rhizosphere soil than the root and root washing solutions. But, the highest solubilization index was exhibited by endophytic bacteria. The p-solubilization index ranges between 1.5 and 2.1 for rhizoplane bacteria, 1.7 and 5.3 for endophytic rhizobacteria, and 1.3 to 3.6 for rhizosphere rhizobacteria with a mean of $1.7,3$, and 2.3 , respectively (Table 3 ).

Table 3. P-solubilization index of rhizobacteria: rhizoplane, endophyte and rhizosphere bacteria.

\begin{tabular}{llll}
\hline Statistics & $\begin{array}{l}\text { P-solubilization index of rhizoplane } \\
\text { bacteria }\end{array}$ & P-solubilization index of endophytes & $\begin{array}{l}\text { P-solubilization index of rhizosphere } \\
\text { bacteria }\end{array}$ \\
\hline Number & 3 & 5 & 9 \\
Mean & 1.7 & 3.0 & 2.3 \\
Range & .60 & 3.60 & 2.30 \\
Minimum & 1.50 & 1.70 & 1.30 \\
Maximum & 2.10 & 5.30 & 3.60 \\
\hline
\end{tabular}

\subsubsection{Diversity of Non P-solubilizing Rhizobacteria}

Ten of the twenty three identified bacteria were Non Psolubilizing rhizobacteria which belong to 5 bacterial genera. These are Pseudomonas (60\%), Bacillus (10\%), Stenotrophomonas (10\%), Enterobacter (10\%), and
Lactobacillus (10\%). The most predominant bacterial species are Pseudomonas viridilivida (30\%) followed by Pseudomonas tolaasii (20\%). Gram negative rhizobacteria dominated the system accounting for $90 \%(9 / 10)$ of the identified non Psolubilizing Rhizobacteria isolates (Figure 3, Table 2).

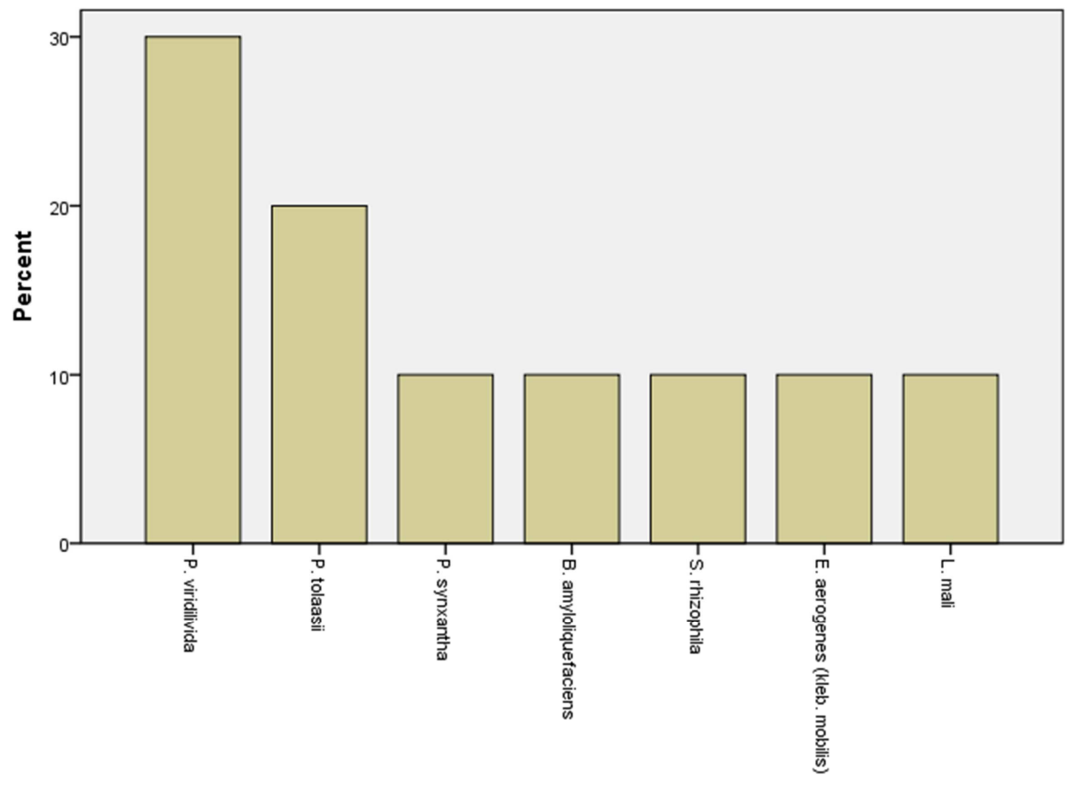

Figure 3. Percent distribution of identified Non-p-solubilizing rhizobacteria species.

\section{Conclusion}

The Rhizobacterial species diversity associated with Sorghum Wild Relative plants are identified in this study. Gram negative bacteria are more predominant than Gram positive bacteria where Pseudomonas is the most dominant Rhizobacterial genus. This study also indicated that there are P-solubilizing rhizobacteria associated with Sorghum Wild Relative which have very large phosphate solubilization index. Thus, it is recommended to include bacteria associated with the wild relatives of sorghum in research program that intends to screen p-solubilizing bacteria for bio-fertilizer development.

\section{Declaration on Conflict of Interest}

There is no conflict of interest.

\section{Acknowledgements}

Our heartfelt gratitude extends to agricultural experts working at each administrative level: Assosa zone, offices of districts, and extension workers found at the smallest administration units where sample collections were undertaken.

\section{References}

[1] Alawiye TT and Babalola OO. (2019). Review: Bacterial Diversity and Community Structure in Typical Plant Rhizosphere. Diversity. 11: 179.

[2] Babalola O. O. (2010). Beneficial bacteria of agricultural importance. Biotechnol. Lett. 32: 1559-1570. 
[3] Babalola O. O., Kirby B. M., Roes-Hill L., Cook A. E., Cary S. C., Burton S. G., and Cowan D. A. (2009). Phylogenetic analysis of actinobacterial populations associated with Antarctic Dry Valley mineral soils. Environ. Microbiol. 11: 566-576.

[4] Biolog's Microbial Identification Systems User's Guide. (2008). GEN III Microplate: Instruction for use. Biolog, Inc. Available online at www.biolog.com.

[5] Costa R, Götz M, Mrotzek N, Lottmann J, Berg G, Smalla K. (2005). Effects of site and plant species on rhizosphere community structure as revealed by molecular analysis of microbial guilds. FEMS Microbiology and Ecology. 56: 236249.

[6] Edi-Premono M., Moawad A. M., Vleck P. L. G. (1996) Effect of phosphate solubilizing Pseudomonas putida on the growth of maize and its survival in the rhizosphere, Indones. J. Crop Sci. 11 (1996) 13e23.

[7] Fanin N. and Bertrand I. (2016). Above ground litter quality is a better predictor than below ground microbial communities when estimating carbon mineralization along a land-use gradient. Soil Biol. Biochem. 94: 48-60.

[8] Getahun A., Kiros S., Muleta D., and Assefa F. (2020). Genetic and metabolic diversities of rhizobacteria isolated from degraded soil of Ethiopia. Heliyon. 6 (2020) e05697.

[9] Gupta S, Meena MK and Datta S (2014). Isolation, characterization of plant growth promoting bacteria from the plant Chlorophytum borivilianum and in-vitro screening for activity of nitrogen fixation, phospthate solubilization and IAA production. 3 (7): 1082-1090 ISSN: 2319-7706.

[10] Hart MM \& Trevors JT. (2005). Microbe management: Application of mycorrhyzal fungi in sustainable agriculture. Frontiers in Ecology \& the Environment. 310: 533-539.

[11] Hijmans R. J., Guarino L., and Mathur P. (2012). DIVA-GIS Version 7.5 Manual. LizardTech, Inc. USA. Available online at website: http://www.diva-gis.org.

[12] IBM SPSS Statistics 25 Core System User's Guide (2017). IBM Corporation 2011 Inc., Chicago, IL, USA, Available online at http://www.ibm.com/spss.

[13] Jime'nez-Salgado T, Fuentes-Ramrez LE, Tapia-Herna' ndez A, Mascarua-Esparza MA, Martnez-Romero E, CaballeroMellado J. (1997). Coffea arabica L., a new host plant for Acetobacter diazotrophicus and isolation of nitrogen-fixing acetobacteria. Applied Environmental Microbiology. 63 (9): 3676-3683

[14] Lucy, M., Reed, E. \& Glick, B. R. (2004). Applications of free living plant growth-promoting rhizobacteria. Antonie van Leeuwenhoek. 86: 1-25.

[15] Midekssa M. J., Löscher C. R., Schmitz R. A. and Assefa F. (2016) Phosphate solubilization and multiple plant growth promoting properties of rhizobacteria isolated from chickpea (Cicer aeritinum L.) producing areas of Ethiopia. Vol. 15 (35): 1899-1912, 31 DOI: 10.5897/AJB2015.15172.

[16] Monk J, Gerard E, Young S, Widdup K and O'Callaghan M
(2009). Isolation and identification of plant growth-promoting bacteria. Proceedings of the New Zealand Grassland Association. 7: 211-216.

[17] Muleta D., Fassil A., Börjesson E., and Granhall U. (January 2013). Phosphate-solubilising rhizobacteria associated with Coffea arabica L. in natural coffee forests of southwestern Ethiopia Journal of the Saudi Society of Agricultural Sciences. 12 (1): 73-84.

[18] Muleta D., Assefa F., Hjort K., Roos S. and Granhall U. (April 2009). Characterization of Rhizobacteria Isolated from Wild Coffea arabica L. Available online at https://doi.org/10.1002/elsc.200700031

[19] Philippot L., Raaijmakers J., Lemanceau P., and Van Der Putten W. (2013). Going back to the roots: The microbial ecology of the rhizosphere. Nat. Rev. Microbiol. 11: 789.

[20] Pikovskaya, R. I. (1948). Mobilization of phosphorus in soil connection with the vital activity of some microbial species. Microbiologiya. 17: 362-370.

[21] Preece C. and Penuelas J. (2016). Rhizo-deposition under drought and consequences for soil communities and ecosystem resilience. Plant Soil. 409: 1-17.

[22] Raj DP and Cherian N (2013) Isolation and characterization of rhizobacteria from forest soils for in vitro study on crop growth enhancement. INT J CURR SCI E. 9: 19-23.

[23] Rodríguez H, Fraga R, Gonzalez T \& Bashan Y. (2006). Genetics of phosphate solubilization and its potential applications for improving plant growth-promoting bacteria. Plant \& Soil. 287: 15-21.

[24] Shukla A. K. (2019). Ecology and diversity of plant growth promoting rhizobacteria in agricultural landscape: Chapter 1 PGPR Amelioration Sustainable Agriculture ISNB 978- 0-12815879-1. https://doi.org/10.1016/B978-0-12-815879$1.00001-\mathrm{X}$

[25] Teshome B., Abatineh E and Ayinalem E. (2019). In vitro Screening and Identification of P-Solubilizing Rhizobacteria Associated with Sorghum bicolor L. Agri Res \& Tech: Open Access J. 20 (2): 556122.

[26] Thanh DTN and Diep CN. (2014). Isolation and identification of rhizospheric bacteria in Acrisols of maize (Zea mays L.) in the eastern of South Vietnam. American Journal of Life Sciences. 2 (2): 82-89

[27] Vessey JK. (2003). Plant growth promoting rhizobacteria as biofertilizers. Plant \& Soil. 255: 571-586.

[28] Yamaoka-Yano DM, Amorim Epr, Valarini PJ, Melo IS, Kosako Y. (1988). Characterization of rhizobacteria from Citrus rhizosphere to control Phytophthora nicotinae var. parasitica and P. citrophthora. Nature Biotechnology. 6 (3): 282-286.

[29] Zhang X., Zhang R., Gao J., Wang X., Fan F., Ma X., Yin H., Zhang C., Feng K., and Deng Y. (2017). Thirty-one years of rice-rice-green manure rotations shape the rhizosphere microbial community and enrich beneficial bacteria. Soil Biol. Biochem. 104: 208-217. 